\title{
RATE ASPECTS OF INSTALMENT LEGISLATION
}

\author{
William Trufant Foster* and LeBaron R. Foster $†$
}

A realistic approach to the problem of instalment credit charges requires concentration on conditions as they are. It should not mark off sectors of the field with boundaries determined by theoretical concepts; nor should it ignore all but a few outstanding agencies, such as the largest finance companies and the largest merchandise distributors. It should embrace the whole field.

To draw an accurate statistical picture of such a large field, however, is impossible with the meagre materials at present available. We do not know how large is the whole; we do not know the size even of any of the constituent parts. We do not know the dollar volume of instalment sales, the volume of instalment credit outstanding at any one time, nor the average rates charged for that credit. Fortunately, we do not need to know any of these things in order to appraise the social worth of present methods of instalment business conduct. Large numbers of case studies, distributed over many states and many commodities, show clearly the nature of the problem.

We assume at the outset-considerable evidence to the contrary notwithstandingthat the consumer is interested in the price he pays for anything, whether that price is for merchandise or for credit granted in connection with the sale of merchandise, and that he would make comparisons of credit costs if the necessary information were provided in sufficiently plain terms.

Does the consumer in fact get that information? In search of an answer, let us consider what we found in one Mid-Western state. ${ }^{1}$ In the sixty stores visited, there were at least twenty-four plans in operation. These twenty-four plans, grouped according to the methods of stating the credit charge, fall into eight broad classifications: (r) a flat dollars and cents charge, with the system for determining that charge undisclosed; (2) a discount from the advertised or list price for cash payment, granted in some stores only if the customer demands it; (3) a flat percentage levied on the

-A.B., 1901, A.M., 1904, Harvard; Ph.D., IgrI, Columbia; LL.D., 1913, Colorado College, rg16, Western Reserve. Director, Pollak Foundation for Economic Research, since I920; Member, Consumers' Advisory Board, N. R. A. President, Reed College, 19ro-1920. Author of numerous works, including (with Waddill Catchings) Money; Profits; Business without a Buyer; The Road to Plenty; Progress and Plenty. Contributor to periodicals.

+S.B., I928 M.B.A., 1931, Harvard. Associate Director, Pollak Foundation for Economic Rescarch. Author, State Regulation of Instalment Selling and Financing, a debate handbook. Contributor to periodicals.

${ }^{1}$ For the method of the study, and the complete table of rates, see LeBaron R. Foster, Instalment Credit Costs and the Consumer, (Jan. 1935) J. Bus. U. of CHr. 27-45. 
cash price, before the down payment is deducted; (4) a percentage per annum levied on the original unpaid balance; (5) a flat percentage, without relation to the length of the terms, levied on the original unpaid balance; (6) a percentage per month on the actual unpaid balance outstanding in each month; (7) "no charge" for instalment credit; (8) a combination of two or more of the above plans.

To shop intelligently, the consumer has to take into account not only all these differences, but many minor variations as well. Some firms require advance payment of the carrying charge with the down payment. Others levy dollars and cents charges which do not check with the advertised percentage plan. Still others refuse to divulge credit terms until the customer has definitely decided to purchase.

We should bear in mind, moreover, that the charges revealed in this study are simply those imposed at the time of purchase. Later in the life of the contract, less reputable dealers, on one pretext or another, sometimes add extra fees. And if the buyer deviates from the exact terms of the contract, he often becomes subject to fines and penalties for irregularity, with no check on the size of those fines other than the seller's self-imposed check of "business expediency."

Now if the customer wants to compare costs of credit at the various available sources, he has only to take his pencil and his courage firmly in hand, and with plenty of time and paper proceed to reduce to a common denominator the differences of price, down payment, length of terms, size of payments and percentage or dollar credit charge. It is not astonishing that few ever attempt such a task!

If credit costs were reasonably uniform, the consumer could ignore these manifold variations in methods of statement; but it is a fact that costs vary widely. In the study just cited, annual cost rates were computed for more than Ioo cases. ${ }^{2}$ Grouped by commodities, the rates ranged as follows:

New Automobiles*

Per Annum Rate

$21.9 \%$ to $32.9 \%$

Used Automobiles* ............................. $34.8 \%$ to $47.1 \%$

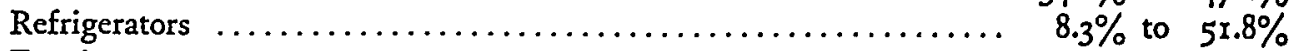

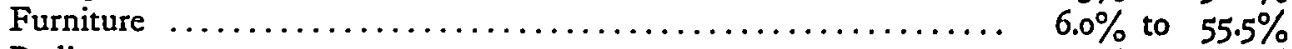

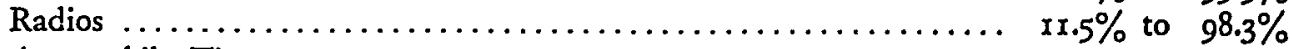

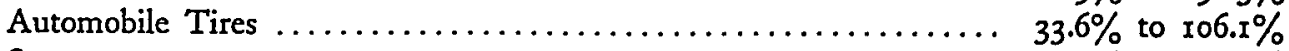

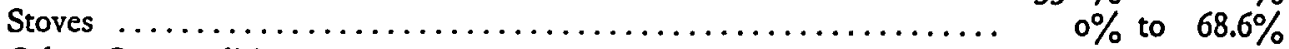

Other Commodities ................................ $0 \%$ to $103.7 \%$

This study does not include extreme cases: the attempt was made to sample the terms which were most frequently used in a given store to finance the sale of a given commodity. Furthermore, the study does not include those unconscionable concerns which send salesmen into the field to contact workers at their homes and places of work, taking wage assignments as security. With such cases included the upper

'The annual cost rate is the ratio of the credit charge (the time price minus the cash price) to the average amount of credit extended for one year, expressed as a percentage. For a comparison of the computation method used in this study and other common methods, see LeBaron R. Foster, stupra note $x$.

* Includes fire, theft, and sometimes collision insurance. 
limits would be far higher. It should be observed that in those few cases where the rate was found to be zero per cent, instalment terms were so short that the average credit extended was less than on ordinary charge accounts.

A comparison of the rates disclosed in the above study with the rates found in a briefer survey conducted in metropolitan Boston discloses no significant differences. The extremes are more pronounced; one Boston store which granted long credit terms refused to make any concession from its instalment price for cash payment, and a small radio shop imposed a credit charge which resulted in a rate of. 353 per cent. But in nearly all cases, instalment rates on a given commodity purchased in a given class of store fell within the ranges observed in the Middle West.

For another study of rates we are indebted to Professor Lewis A. Froman of the University of Buffalo. ${ }^{3}$ The following is a summary of his tables:

Per Annum Rate

New Automobiles ("one of the largest and most representative automobile

finance companies") $\ldots \ldots \ldots \ldots \ldots \ldots \ldots \ldots \ldots \ldots \ldots \ldots \ldots \ldots$. $4 \%$ to $38 \%$ *

Electrical Appliances ("large eastern public utility company")......... $13 \%$ to $23 \%$

Electrical Refrigerators ("one of the largest general finance corporations") $14 \%$ to $30 \%$

Mail-order Goods ("a well-known mail-order house") ............. 13\% to $66 \%$.

- Rates do not include mandatory insurance charge.

Here the ranges represent the difference in cost between long terms on large amounts of credit and short terms on small amounts of credit. Though representative of only a part of the instalment financing business, they probably are typical of large, efficient concerns which charge enough to meet credit costs. However, it is important to bear in mind that the finance company rates do not include the "pack," or extra charge, which the dealer often adds for his personal profit. ${ }^{3 *}$

We know, then, that rates may be very low or very high. We know, likewise, that the consumer rarely can figure the true rate for himself from the confused terms in which charges are stated. We may add to these deductions the fact that the consumer cannot rely on the percentages frequently quoted as the basis for charges, even when they appear to be clear and exact. In the Mid-Western study, only one store out of 60 described its charges in terms of a true percentage rate. That store, isolated on its isle of honesty, might ironically be charged with deception: it was not playing the game of deceiving its customers. Among the other stores, the quoted rates showed so many degrees of variation from the actual rates that it was not possible for a customer to draw any conclusions as to comparative costs.

Patently, the need is for a uniform, accurate, outspoken method of statement, universally applied wherever instalment credit is granted. To be doubly useful, the method should permit comparison not only among various sources of instalment merchandise credit, but also with sources of cash credit. Although there are dif-

${ }^{3}$ Froman, The Cost of Instalment Buying (1933) 8 Harv. Bus. Rev., 227.

"The problem of the "pack" is discussed in, Cavers, The Consumer's Stake in the Finance Company Code Controversy, infra, at p. 204 et seq. 
ferences between merchandise loans and money loans, the two may be used for the same purpose, and are in fact so used to some extent today.

What are the alternatives? We might fall back on the commercial banking custom of discounting interest in advance, in accordance with the current practice of industrial or Morris-Plan banks and personal loan departments of commercial banks. But the discount method always makes the rate appear lower than it is. On a straight loan maturing at the end of one year, to per cent discounted in advance is equivalent to a true rate of II.I per cent. And on an instalment loan, the method does not reflect the periodic reductions of the principal through repayments, except when repayments are treated as deposits and interest is paid on them. As a consequence, the true rates for such loans are always several fathoms below the surface. For example, a to per cent discount on a one-year loan repayable in equal monthly instalments, with interest at three per cent credited on repayments, results in a true rate of approximately 18 per cent.

Typical of discounted instalment loans which do not involve interest credits on repayments are those guaranteed by the Federal Housing Administration. As late as March, 1935, an Administration official said: "The interest rate is arranged locally between the borrower and the local lending agency, except that it may not exceed five per cent per annum." And a federal government advertisement said that the yearly interest charge was $\$ 5$ for each $\$$ roo borrowed. Possibly the government should not be blamed for falling into line with the standard practice of the banks which are to make the loans. Discounting is their method and their habit. But there is no excuse for misinforming consumers in official pronouncements which are intended only for consumers. In the first place, when \$roo is discounted at five per cent the borrower receives an actual advance of only $\$ 95$. Further, the loan is repaid periodically by instalments, with the result that the borrower has, on the average, the use of only a little more than half the original advance. The result is a true rate of 9.7 per cent per annum, not five per cent. The borrower should not be required to pay interest on the discounted interest, nor on the principal he has paid back.

Another alternative is the method, common in department stores, of charging an annual percentage on the original unpaid balance. The first objection is that the method calls the rate something that it is not; a six per cent rate may work out to anything from six to 12 per cent, depending on the length of the terms. Another objection is that some sellers take advantage of the buyer's assumption that the rate is annual, when in fact they apply the full percentage for a period of six or eight or ten months. Again, the method results in the highest rates on the longest terms, whereas it is on the longest terms that the cost to the credit grantor is lowest.

With one exception, all the other methods in common use are open to similar misunderstanding and abuse. The one exception is the statement of the credit charge, including interest, investigation, service, commission, bookkeeping and all

- Ward M. Canaday, Director of Public Relations, Federal Housing Administration, $A$ Beffer Place in Which to Live, Rural Progress Magazine, March, 1935, p. 3. 
other charges and fees of every description, as a per cent per month on the average balance outstanding in each month. This is the method successfully employed in the administration of small loans under the Uniform Small Loan Act. It does not permit juggling of discounts, down payments, percentages, advance payments or fees. It provides an automatic method for figuring rebates of carrying charges, in case the buyer repays any part of the principal before the due dates. And it conforms realistically with the costs of granting credit: the seller collects the largest part of the carrying charge in the early part of the contract, when his costs are highest, and the smallest part towards the end of the contract, when his costs are lowest. The one plausible objection is that it might present some administrative difficulties in the financing of the smallest balances, particularly while the credit personnel was becoming accustomed to the change in routine.

Granted that a uniform, clear, outspoken method of instalment cost statement is desirable, how may it be brought about? Not by the individual instalment seller. A few furniture and piano stores, to be sure, have adopted the per cent per month method, but the great majority apparently believe, and with some reason, that if they told the truth about their rates they would lose business to competitors who continued to disguise or conceal their rates. Only before an enlightened buying public could the truth teller gain the advantages of his frankness, and education of the buyer will be slow as long as each instalment buying experience further confuses him.

What each cannot do singly might be done collectively through the trade organization. But the attitude of the largest finance companies and of their trade organization is that a comparison of dollar charges for credit is good and sufficient; that an interest rate approach to the problem is inexpedient, since, they say, the instalment financer does not make a loan but simply renders a service; that buyers are not interested in percentages. The finance companies contend, in short, that present methods of stating rates are adequate.

Nor does there appear to be much to expect from the NRA codes. For eighteen months the Consumers' Advisory Board has been asking that provisions be inserted in the Retail Trade codes, requiring accurate percentage statement of instalment credit carrying charges.

The official statement of the Board's position is:

x. "Whenever goods are sold on deferred payment the seller performs two distinct and separate functions-the sale of merchandise, and the extension of credit for which a charge is made.

2. "Whenever a charge is made for the extension of credit this charge, like the price of merchandise, should be stated in terms which make it readily comparable with all prices for the use-of-money repayable in monthly installments.

3. "There is only one accurate way to express the price of the use-of-money-by a given percentage on a given principal for a given time. Any other method of statement permits juggling with one of the two variables,--principal and time. 
4. "In installment credit the outstanding amount of credit declines from month to month. Therefore, the only accurate and outspoken way to express the charge for this type of credit is in terms of a given percentage on the current unpaid monthly balance."

In not a single NRA code has such a provision been adopted. Though the Roosevelt Administration is becoming increasingly aware of the need for consumer protection, so far codes have been framed for the most part in the interests of business and labor.

If truthful rates are not to come yoluntarily, they may come coercively through state laws. In the forefront of the movement stands Indiana. When, in March, r935, the Legislature passed and the Governor signed the Retail Instalment Sales Act, the State distinguished itself as the first to pass a comprehensive law regulating the business of instalment selling and financing. As introduced, the Bill (H. 377) contained several provisions bearing directly on rates, chief among which were the following:

(I) "No retailer may collect or receive a greater rate of interest than two-thirds of one per cent ( $2 / 3$ of $I \%)$ per month on the principal balance owing on any retail instalment contract from any retail buyer . . ." " ... interest may not be collected in advance and shall be computed only on the number of days the principal balance or any part thereof remains unpaid." This restriction was to apply only to unlicensed retailers.

(2) Licensees of the state banking department, on the other hand, were to be allowed to collect or receive any lawful rate of interest contracted for in the retail instalment contract. The department was to be empowered to fix a fair maximum rate of interest-either a single rate or a series of rates established by classes, and to prescribed maximum fees where fees were to be permitted. The annual license fee was to be $\$$ Ioo.

(3) Banks and trust companies were to be restricted to an interest rate of $x \frac{1}{2}$ per cent per month upon the principal balance owed.

The Bill ran the gauntlet of legislative amendment. Rate features were radically altered. All references to finance charges as interest and all requirements for statement of finance charges on a percentage basis were eliminated. In their place were substituted rigid requirements for accurate statement of the dollar amounts of carrying charges. Section 4 provides:

"Every written instrument evidencing a retail instalment sale shall recite. . . .

"(I) The cash price of the specific goods.

"(2) The amount in cash of the retail buyer's down payment, whether made in money or goods or partly in money or partly in goods.

"(3) The unpaid balance. ..."

"(4) The cost to the retail buyer of any insurance the retail seller has agreed to procure, if the retail seller has agreed to purchase the insurance and extend credit to the retail buyer for the price thereof. 
"(5) The principal balance owed on the retail instalment contract which is the sum total of items (3) and (4).

"(6) The amount of the finance charge.

"(7) The time balance owed by the retail buyer to the retail seller and the number of instalment payments required and the amount and date of each payment necessary finally to pay the time balance which is the sum total of items (5) and (6)."

The price of the insurance may be included in the finance charge, and item (5) omitted; but if this procedure is followed, the retail seller shall, within twenty-five days, mail the retail buyer a statement reciting the separate amounts of items (4) and (6).

But the teeth of the regulation rests, potentially, at least, in Section 6:

"The finance charge contracted for in any retail instalment contract may not exceed the maximum finance charge then authorized by the department. . . .

"Every retail buyer shall have the right, at any time, to pay the then unpaid time balance owed. ... The department shall and is hereby authorized to fix and determine the amount of any discount to be given for prepayment. . . ."

As finally passed, therefore, the Act attempts to establish satisfactory instalment rates, not by providing buyers with a uniformly applied yardstick of credit costs, but by authorizing the Department of Financial Institutions to limit and watch over charges. Thus, presumably, consumers are safeguarded. against exorbitant carrying charges. Unfortunately, however, the law does not require the seller to provide sufficient information to enable the buyer to make cost comparisons. Little better than before this law was passed can the individual purchaser tell whether he may obtain credit most cheaply from store $A$, from store $B$, or from any one of several sources of money loans.

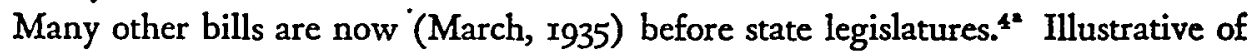
provisions affecting rates are those summarized below:

ArRansas

House Bill No. 275.

Financing agencies must designate what part of the carrying charge is interest, and "when said amount of interest taken together with any other charge for handling or carrying charge exceeds ten per cent per annum it will be usury." Instalment sellers who take conditional sales contracts are placed under a similar restriction. Insurance charges may not be included in the carrying charge, but must be treated separately.

INDIANA

House Bill No. 373 .

This amendment to the banking laws empowers banks and trust companies to make Federal Housing Administration loans, but provides that "any bank or trust company shall have power to make loans or advances or credit for a period not to exceed one year and in amounts not exceeding one thousand dollars, repayable in installments, upon the security of co-makers, personal endorsement or the pledge or mortgage of personal property or choses in action and to charge therefor and a rate

“Eprtor's Notz: Of the bills discussed below, the Michigan bill has passed the House, and is now (May, 1935) before a Senate committee. The other bills have failed of enactment. 
of interest thereon not exceeding one and one-half per cent per month upon the unpaid balance of any such loan, provided that it clearly appears upon the face of the instrument evidencing such loan that the rate of interest charged thereon is to be computed upon the basis of the stated rate per month upon unpaid balances; and no other or additional charge shall be made for any such loan, except recording fees, if any, actually paid."

\section{MASSACHUSETTS}

Senate Bill No. 55 .

This bill governs, through licensing, all persons regularly engaged in the business of selling personal property of a value of $\$ 1000$ or less on conditional sales contracts, bailments and leases, and all persons regularly engaged in the business of financing or refinancing sales of personal property and services rendered to a consumer of a value of $\$ 1000$ or less.

Rates are not restricted, but the contract, a copy of which must be given to the buyer, shall "state with substantial accuracy [in the contract] all the terms and conditions of the contract and shall include: the cash market value of the goods or services; the down payment in dollars and cents; the original balance financed; the number of weeks or months covering the duration of the contract; the amount of the weekly or monthly payment in dollars and cents; the interest, service charges or credit charges stated both in dollars and cents, and as a per centum per month, calculated on the average unpaid balance outstanding in each month." "The intercst, service charge or credit charge shall include all charges for interest, service, investigation, bookkeeping and all other charges made in connection with the contract. No other charges, bonus, fee, expense or demand of any nature whatsoever shall be made so long as the buyer fulfils the conditions of the contract; and no fines, penalties or charges shall be made for delay, delinquency, repossession, refinancing, legal expense or other cause unless such charges are specifically set forth in the contract both as to amount and as to the conditions under which they may be imposed."

Where the seller places a policy of insurance to cover his insurable interest in the article sold, the amount of insurance, the kind of insurance, and the premium paid shall be stated in the contract, and the premium shall be added to the item of the original balance financed.

Senate Bill No. 4 .

All those engaged in the business of financing or refinancing the purchase of personal property shall be licensed, and the Commissioner of Banks is empowered to issue rules and regulations and to examine licensees.

House Bill No. 805.

This bill contains provisions similar to those in Senate Bill No. 4 , above, and in addition provides that the Commissioner shall establish a rate "which shall not in the aggregate exceed an amount equivalent to ten per cent per year on the amount 
actually loaned or advanced for the account of the purchaser." Interest shall include all sums paid by, for or on account of the purchaser, for or on account of making the advance.

\section{Michigan}

House Bill No. 459.

As originally introduced, the bill contained provisions requiring adequate informing of the buyer as to all credit terms and costs, including the statement of the carrying charge as a per centum per month calculated on the average unpaid balance outstanding in each month. But the Committee on Judiciary recommended a substitute for passage, which was adopted. The substitute requires merely that seller shall provide the buyer with a copy of the chattel mortgage or conditional sale contract, and that the contract shall recite:

"(I) The cash price of the specific goods.

"(2) The amount in cash of the retail buyer's down payment whether made in money or goods, or partly in money or partly in goods.

"(3) The unpaid balance of the cash price payable by the retail buyer to the retail seller which is the difference between items (I) and (2).

"(4) The amount of the finance charge stated in dollars and cents.

"(5) The time balance owed by the retail buyer to the retail seller, and the number of installment payments required, and the amount and date of each payment necessary finally to pay the time balance which is the sum total of items (3) and (4)."

The only restrictive feature is provided in Section 4: "No Finance Charge by the Seller shall be charged, contracted for or received in excess of the finance charge that shall have been advertised, printed or displayed in any publication or written communication of the Seller."

The bill does not require a separate statement of the cost of insurance included in the finance charge, nor does it in any other way alter the present practices of reputable sellers. However, the passage of the bill would accomplish one important purpose: it would establish the right of the state to regulate instalment selling.

\section{New HAMPSHIRE}

\section{House Bill No. 253.}

"It shall be illegal for any company operating within the state to make charges in excess of fifteen per centum per annum, of the valuation of any automobile for loaning money to purchase said automobile."

\section{New YoRk}

\section{Assembly Bill No. 940.}

The banking laws covering loans of money, credit, goods, or things in action of a value of $\$ 300$ or less are extended to include the purchase of notes or bills at a discount. Presumably the intent is to bring under the small loan law industrial banks 
and others lending small sums on a discount basis. However, through judicial interpretation instalment finance companies might conceivably be included.

In these bills is displayed a wide range of regulatory theory and application. In some, a destructively low rate is set; in others, the rates now governing small loans are applied; in others, no légal maximum is established. In general, the underlying philosophy may be divided into two schools of thought: $(x)$ the consumer can be protected from exploitation only by setting a legal maximum rate, and (2) where competition is reasonably free the consumer is adequately protected when he is informed as to the true size of credit charges, in terms of a uniform, clear standard. The second point of view seems to be favored both by the theoretical objection to price fixing and by the failures of price fixing in practice.

Again the argument rests upon a realistic approach. Retail instalment selling at present is employed in sales varying all the way from $\$ 5$, with payments spread over a few weeks, to three thousand dollars, with payments spread over three years. A large part of the costs of granting credit are fixed. Cost of legal forms, bookkeeping, credit investigation, routine collection and filing are about the same for a small contract as for a large contract. The spreading of these fixed costs over a small balance and a short term inevitably results in a high percentage rate. Yet under some circumstances the buyer may find it well worth while to pay the high rate rather than go without a needed purchase.

To illustrate: representative instalment terms on tires are a down payment of ro per cent, the balance plus ro per cent of the cash price to be paid in to weekly instalments. Because of the brief period of repayment, the rate is ros per cent. Yet the buyer, if unable to scrape together \$ro for a new tire, might willingly pay the \$x carrying charge rather than go without the use of his car until he had saved \$ro. If one dollar a week was all that he could spare from his wages, his car might lie idle for two and one-half months.

The advocate of an arbitrary legal maximum rate might hold that, since the buyer pays an improvidently high rate for the credit, he should be protected against his own folly. But who is to draw the line? The impoverished housewife who can save money by doing her own washing in a washing machine, the salesman who cannot reach his customers without a car, the long-unemployed clerk who has at last found a job but who cannot pay cash for the necessary clothes, all these and countless others may profit from purchasing on the instalment plan, even at high rates. The great majority must either obtain consumer credit, which usually means expensive credit, or go without the needed goods. No one but the individual can decide whether the credit is worth the price. The one protection which might be provided by law, without limiting the scope of the service, is the requirement that sellers state their charges in accurate, comparable terms.

Is instalment credit too expensive? Who can say? Certainly it is more expensive than it will be a few years hence. But lower rates will come through improved 
methods of doing business or through increased competition, not through legislative enactment. Experience in the small loan field proves that the setting of an arbitrary maximum rate below the level at which lenders can meet costs merely deprives borrowers of a valued loan service.

Should some state enact a low maximum rate, of fifteen per cent per annum, for example, the effects logically to be anticipated are: (I) elimination of instalment selling as a credit instrument for sellers who impose carrying charges adequate to meet costs; (2) increased business for firms which cover a substantial part of credit costs in their "cash" prices, with the result that cash buyers pay for credit whether they take it or not; (3) evasion and underhanded dealing on the part of the less reputable sellers.

Possibly in the end it will be found that a legislated maximum rate is fairest to both consumers and sellers. But until trial and error with more liberal regulatory measures has provided a background of experience, legislatures will do well as an initial step to bring the business under regulation and supervision. Presumably that is why sponsors of the Indiana Bill were content to allow the striking out of features which were most objectionable to the instalment finance business. Once the state has established its power to control-to license, to investigate records and accounts, to issue rules and regulations, to fix maximum rates-then the moulding of policy and the strengthening of legislation to deal with new situations as they arise, or with old needs as they become clarified, should follow as a matter of course. 